\title{
PREPARATION THE FUTURE DESIGNERS FOR PROFESSIONAL CAREER DEVELOPMENT: PEDAGOGIC EXPERIMENT RESULTS AND RESEARCH PROSPECTS
}

\author{
Valentyna Radkevych ${ }^{1}$, Svitlana Aleksieieva ${ }^{2}$,
}

1 Doctor in Pedagogic sciences, Profesor, Academician of NAES of Ukraine, Director Institute of vocational education and training NAES of Ukraine

http://orcid.org/0000-0002-9233-5718

e-mail:mrs.radkevich@gmail.com

2 Candidate in Pedagogic sciences, Senior researcher the Laboratory on professional life Institute of vocational education and training NAES of Ukraine http://orcid.org/0000-0002-8132-0465 e-mail: SV-05@ukr.net

\begin{abstract}
The problem of an individual's career development is getting crucial for modern pedagogy and is considered as wisely chosen way for reaching the top of his/her professional mastering, self-realisation and successful social status. Modern future designers training for their professional career development is based on the dialogue interaction with participative practices (involvement), facilitating technologies (group work), vitagene technologies (life experience actuality). Its important feature is ICT and tools use (social networks, "cloud" services, digital-communicative resources, multimedia programs, information-visual systems) organized in the one information-education environment. The appropriate training content development as the entire system should include the main three components: cognitive (knowledge), process (skills), personal (qualities, values, emotions) and active use of ICT (forming motivation for career development and its appropriate skills; self-education management on career development). They highly promoted increasing the future designer's readiness level for professional career development. The results of pedagogical experiment enforce the prospective ways for future designers training for their professional career development. They are the counseling system improvement and the appropriate information network creating, providing psychological and diagnostic services of professional guidance and defining the readiness level for professional career development; professional and career oriented education programs development; teachers training and upskilling improvement; ordering the government actions and developing the system of activities for solving the following problem.
\end{abstract}

Keywords: professional career, information-analytic site, on-line counseling, information-communication tools, methods for life experience stimulating and updating.

Introduction. The profession of a designer in Ukraine is becoming one of the most on-fire occupations. It is in the top vacancies at the labour market. This is proved by the report results of recruitment and consulting companies. At the same time, the number of students aspiring to become a designer in the Ukrainian professional (vocational), pre-tertiary vocational and high education institutions is increasing. It follows that the necessity of researching the mentioned issues is updated. It will promote the quality improvement of design (arts) education in accordance with an individual's abilities and capabilities, as well as the needs of society in highly educated, creative and career-oriented artistic professionals (Radkevych, 2010).

The research problem is harmonised with the modern concept on sustainable development for the society. It considerably extends the individual's possibilities to choose ways of life and active role in the society, gaining social independence, ensuring 
effective professional interpersonal interaction, continuous skills improvement etc. For this reason, a professional career is considered as a consciously chosen way of achieving the peaks of the individual's professional self-realization, his/her successful genesis in the society.

Materials. The theoretical and practical principles of professional training for future designers were substantiated in works by I. Ryzhov, S. Chyrchyk, V. Tyomenko, V. Orlov, O. Fursa, I. Rozenson, A. Troshkin, T. Udod, O. Shvets. M. Zakharov, I. Zymnia, D. Normann, E. Pavliutenkov, M. Poddiachyi, M. Priazhnikov, Yu. Tatur, B. Fedoryshyn, A. Khutorskyi, S. Chystiakov and others studied scientific approaches to professional guidance organising, self-determination and the individual's professionalisation, in particular systemic, competence, managerial, informational etc. However, the issues related to future specialists' training for their professional careers development are not sufficiently highlighted. The relevance of the problem is evidenced by the recent research results. Namely, defining the concept of professional careers (L. Basyl, L. Ershova, B. Pochebut, L. Dolgikh, M. Suriakov, D. Zatatnov) makes it possible to determine the process as a consciously chosen way of reaching the professional perfection peaks, professional implementation, successful mastering the profession. L. Yershova $(2017,2018)$ studied the motivation peculiarities for choosing a profession and developing a professional career. In her studies, it is noted that the success and quality of mastering the specialty is observed when the choice is driven by motives related to significant value orientations and personality settings. It also indicates the need to form the internal motivation of the professional choice and the development of a professional career.

It is necessary to emphasise the importance of research results by V. Orlov (2015). The scientist argues that the successful designer in the modern world will be the one with formed career potential, not looking for a job but for opportunities for his/her creative ideas realisation, self-determination and selfrealisation. In this context, the justified provision by V. Radkevych (2016) on the importance of step-bystep professionalization for future specialists' career, in particular the designers. It is realised from selfdetermination and professional development up to the continuous professional advancement.

L. Basyl (2018) emphasises the need for professional career counselling for future specialists. In her opinion, the career counselling is an important factor in future professionals' self-realisation. According to D. Zakatnov (2012), there is a waiver of traditional understanding the professional success of a specialist due to his/her position in favour to a person's status as an active developer of his/her own career. For these reasons, the professional career in design becomes an important indicator of the individual's social and professional achievements. It enables him/her to realize own abilities, needs, ambitious plans in the context of career development. As noted by V. Radkevych (2016), in such a career the dynamics of professional development is determined by the career cycles. They consist of ministages of professional development. The transition from one stage to another is accompanied by short but intensive training or advanced training terms.

Research aim. Based on analysis the empirical data of the experimental work, justify the training prospects for future designers in the line of their professional careers development.

Methods. Data statistical analysis (calculation Pearson, Student and Fisher criterion); Spierman's formula; variation series compilation; data correlation and factor analysis; calculating the confidence intervals of random size; using the table of "reasonably large numbers" to determine the number of observations; content analysis are used.

Results and discussions. The future designers' readiness for their professional career development will be efficient if it has the scientific-based theoretical and methodological foundations, reflecting the leading methodological approaches, didactic principles, as well as the pedagogical system. The system should cover the practice-oriented content, forms, methods, innovative technologies and the appropriate training approaches in the arts colleges. The introduction of the pedagogical system is based on dialectically interrelated components and elements implementation, providing optimal conditions for solving the tasks of getting the future designers ready for their professional career development.

The pedagogical system of getting the future designers ready for their professional career development combines components of a holistic pedagogical process - from goals to results - and focuses on a future designer's personality. He/She should use the technologies of professional development and be highly prepared for this process. The following system includes: priority goals, aimed at achieving the high level of professionalism for future designers; principles and contents, aimed at assimilating the components of training; careeroriented knowledge of skills and skills that are formed while studying the corresponding modules of educational disciplines, the author's training course; pedagogical conditions to ensure the effectiveness of realization the career orientation of design activity; 
methods, forms, means, methods of control and correction and the result that characterizes the achieved changes in accordance with the objectives. Such a system reflects the structural and functional interaction of the motivational, cognitive, operational and technological components of vocational education and training (VET), the general and specific principles of training, the complexes of knowledge and skills that form the basis of the career competence of the future designer, the methodical component of preparation, a set of criteria and indicators of the formation of levels of preparedness before developing a professional career (initial, adaptive, high).

Increasing the level of future designers' readiness to develop their professional career contributes to the didactic structured content of such training as a holistic system that includes three main components: cognitive (knowledge), procedural (skills), personal (qualities, value orientations, emotional states).

The preparation of future designers for their professional career development is based on the principles of interactive interaction through the introduction of participatory practices (involvement), technologies of facilitation (group work), vita technology (actualization of life experience). The main methods are aimed at motivating students to studying and cognitive activity, contextual education, and stimulation methods - to update their life experience. To this end, the innovative training technologies were actively used, in particular: creating motivation for the professional career development; forming the future professional designers' knowledge and skills in their professional careers development; self-education activities managing for the professional career development etc.

The technology of forming motivation for the professional career development has made it possible to purposefully influence the personality. It focuses attention both on external motivation and on the internal one. The implementation of motivation technology was carried out in three stages. The first stage - the initial motivation - took place in the first year and is associated with the process of inducing future designers to studying and developing the professional career. The initial motivation is realized as an interest in new, interesting facts of career development by historical references of biographies of well-known designers, researches of modern career opportunities, trends of labour market development. That positively motivates students. The second stage was realized on 2-3 courses of study and is connected with the stage of motivation maintenance. At this stage, teaching methods are used to motivate students for achieving mental and practical activity: the recommended trainings, talk-shows, "brainstorming" are implemented. The third stage involves the 4th course students and is associated with the stage of final motivation. It requires creating the situation of success, the inclusion in collective design, projectbased, research, discussion activities, managing team work and role playing games.

The important feature of getting the future designers ready for their professional career development is ICT use (social networks, cloud services, electronic communication resources, multimedia programs, information and visual systems). They should be organised as a single information and educational environment (Aleksieieva, 2015). Accordingly, that was carried out through information and training site, online counselling and online training. That provided the efficient solving the problem information presentation recency, to make the process interesting via its visualization and individualization (Aleksieieva, 2016).

The experimental research was carried out on the basis of colleges (Art College of Art Modelling and Design (Kyiv), KNUBA Vinnitsa College of Construction and Architecture, Zhytomyr College of Culture and Arts named after I. Ogienko, KNUTD College of Arts and Design (Kyiv). The estimation of future designers' readiness level for their professional careers development was carried out by motivational-emotional, cognitive-developmental, technological, personal-volitional criteria. Interpretation-theoretical and empirical research methods were used to solve those tasks.

Experimental and control groups were formed for conducting a parallel experiment (the number of students for each control group - 199 persons, experimental ones -202 persons). According to the parallel experiment logic, the students training was based on the traditional training system. Thus, for the experimental groups they were changed. According to the indicators of incoming diagnosis, the difference in the results in the training did not exceed $2 \%$. The homogeneity of the samples by qualitative composition makes it possible to obtain objective results at the end of the experiment. In addition, the experiment took place in the usual training environment. It allows taking into account and repeatedly reproducing the investigated phenomena.

The results of the diagnosis indicate a significant increase in the level of future designers' readiness for their professional careers development. For example, according to the motivational-emotional criterion, redistribution occurs due to the entry level. In particular, in the experimental group, the number 
of students with the initial level of motivation formation to achieve the career success decreased by $-7,92 \%$ (from $14,36 \%$ to $6,44 \%$ ); in the control group - by $5.53 \%$ (from $14.07 \%$ to $8.54 \%$ ). The formative stage of the experiment has significantly changed the distribution of the entry level by the indicator of "interest in career activities." In the experimental group there was a decrease in the number of students with professionally significant technologies for planning career development at $-16.83 \%$ (from $18.81 \%$ to $1.98 \%$ ), in the control group - by $2.51 \%$ (out of $18,09 \%$ on $-15.58 \%$ ). Accordingly, we state that there is a redistribution and at the creative level. In the experimental groups there was an increase in the number of students capable to analyse specific professional situations by $-13.85 \%$ (from $48.03 \%$ to $61.88 \%$ ); in the control group - by $4.52 \%$ (from $47.74 \%$ to $52.26 \%$ ) (Table 1 ).

The graphic representation of the research results indicates the positive dynamics of future designers' readiness for their professional careers developing (Fig. 1).

The results of the given data give grounds to speak about the positive influence of the developed and scientifically substantiated pedagogical system for

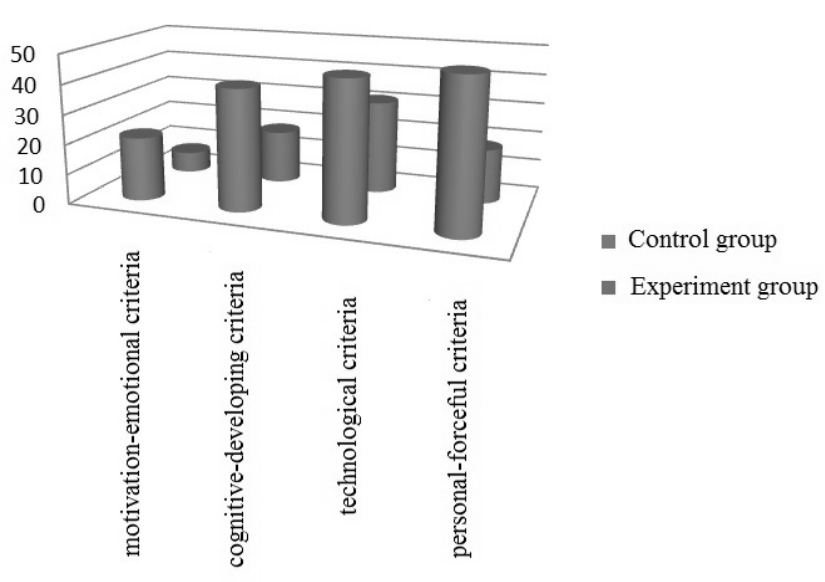

Fig. 1. Research results diagram on getting the future designers ready for their professional career development

increasing the level of future designers' readiness for their professional careers developing. Accordingly, in the future, it is envisaged to create the informational network of career counseling and diagnostic services for professional guidance and determination of the level of readiness for professional career development; improvement of educational programs focused on professional and career advancement.

\section{Table 1}

Comparing results for ascertaining and forming experiment stages

\begin{tabular}{|c|c|c|c|c|c|c|c|c|}
\hline \multirow[t]{3}{*}{ Experiment stages } & \multirow[t]{3}{*}{ Groups } & \multicolumn{6}{|c|}{ Levels } & \multirow[t]{3}{*}{$\chi^{2}$} \\
\hline & & \multicolumn{2}{|c|}{$\begin{array}{c}\text { Initial } \\
\text { (insufficient) }\end{array}$} & \multicolumn{2}{|c|}{$\begin{array}{l}\text { Adaptive } \\
\text { (sufficient) }\end{array}$} & \multicolumn{2}{|c|}{$\begin{array}{c}\text { High } \\
\text { (creative) }\end{array}$} & \\
\hline & & $\%$ & $\begin{array}{l}\text { EG- } \\
\text { CG }\end{array}$ & $\%$ & $\begin{array}{l}\text { EG- } \\
\text { CG }\end{array}$ & $\%$ & $\begin{array}{l}\text { EG- } \\
\text { CG }\end{array}$ & \\
\hline \multicolumn{9}{|c|}{ motivation-emotional criteria } \\
\hline \multirow[t]{2}{*}{ Ascertaining } & $\mathrm{CG}$ & 21,36 & \multirow{2}{*}{$+0,3$} & 35,30 & \multirow[t]{2}{*}{$-0,28$} & 43,34 & \multirow[t]{2}{*}{$-0,02$} & \multirow[t]{2}{*}{0,035} \\
\hline & EG & 21,66 & & 35,02 & & 43,32 & & \\
\hline \multirow[t]{2}{*}{ Forming } & CG & 16,59 & \multirow{2}{*}{$-9,53$} & 34,17 & \multirow[t]{2}{*}{$+1,47$} & 49,24 & \multirow[t]{2}{*}{+8} & \multirow[t]{2}{*}{7,195} \\
\hline & EG & 7,06 & & 35,64 & & 57,30 & & \\
\hline \multicolumn{9}{|c|}{ cognitive-developing criteria } \\
\hline \multirow[t]{2}{*}{ Ascertaining } & $\mathrm{CG}$ & 40,50 & \multirow{2}{*}{$+0,2$} & 36,68 & \multirow[t]{2}{*}{$-0,35$} & 22,82 & \multirow[t]{2}{*}{$+0,15$} & \multirow[t]{2}{*}{0,217} \\
\hline & EG & 40,70 & & 36,33 & & 22,97 & & \\
\hline \multirow[t]{2}{*}{ Forming } & $\mathrm{CG}$ & 35,98 & \multirow{2}{*}{$-18,16$} & 37,08 & \multirow[t]{2}{*}{$-0,73$} & 26,94 & \multirow[t]{2}{*}{$+18,89$} & \multirow[t]{2}{*}{8,277} \\
\hline & EG & 17,82 & & 36,35 & & 45,83 & & \\
\hline \multicolumn{9}{|c|}{ technological criteria } \\
\hline \multirow[t]{2}{*}{ Ascertaining } & CG & 46,20 & \multirow{2}{*}{$+0,53$} & 36,45 & \multirow[t]{2}{*}{$-0,41$} & 17,35 & $-0,12$ & 0,196 \\
\hline & $\mathrm{EG}$ & 46,73 & & 36,04 & & 17,23 & & \\
\hline Forming & $\mathrm{CG}$ & 41,70 & -105 & 38,60 & $-0,3$ & 19,70 & $+10,8$ & 7,754 \\
\hline & EG & 31,20 & & 38,30 & & 30,50 & & \\
\hline & & perso & -forcefu & iteria & & & & \\
\hline Ascertaining & $\mathrm{CG}$ & 49,75 & +055 & 33,57 & $-0,3$ & 16,68 & $-0,25$ & 0,142 \\
\hline & EG & 50,30 & & 33,27 & & 16,43 & & \\
\hline Forming & CG & 45,02 & -2691 & 36,18 & $+3,43$ & 18,80 & $+23,48$ & 8,261 \\
\hline & EG & 18,11 & & 39,61 & & 42,28 & & \\
\hline
\end{tabular}


Conclusions. Thus, the efficiency of getting the future designers ready for their professional career development as a general pedagogical phenomenon with the corresponding structure and content is ensured by the organic combination of traditional and innovative methods, forms, technologies and learning tools based on mutual complement and reinforcement. In the future, the direction of this study will be aimed at improving the counselling system on professional career development and encouraging the continuous career self-development for future specialists; improvement pedagogical workers training and retraining for the following process implementation; ordered management actions realisation and the a system of measures creation for solving the given problem.

\section{List of references}

Алєксєєва, С. В., 2015. Інформаційне освітнє середовище підготовки майбутніх дизайнерів до розвитку професійної кар'єри. Науковий вісник Інституту професійно-технічної освіти НАПН Украӥни. Професійна педагогіка: зб. наук. праць, 10, с. $72-78$.

Алєксєєва, С. В., 2016. Форми та методи он-лайн консультування майбутніх фахівців з розвитку професійної кар'єри. Сучасні інформаційні технології та інновачійні методики навчання в підготовиі фахівиів: методологія, теорія, досвід, проблеми: зб. наук. праць, 44, с. 194-198.

Базиль, Л. та Орлов, В., 2018. Консультування із професійної кар'єри як важливий чинник самореалізації майбутніх фахівців. Science and education a new dimension. Pedagogy and Psychology, VI (75), Issue 181, Nov, c. 7-11.

Єршова, Л. М., 2017. Гендерні особливості мотивації учнів професійно-технічних навчальних закладів до вибору професії та розвитку професійної кар'єри. Науково-методичне забезпечення професійної освіти і навчання: збірник матеріалів ХІ Всеукраїнської науково-практичної конферениї (звітної), присвяченої 25-річчю НАПН України. Київ, Україна, 29 Березень - 13 Квітень 2017, с. 134-137.

Єршова, Л., 2018. Науково-експериментальні дослідження як мотиватор розвитку професійної кар'єри. В: Науково-методичне забезпечення професійної освіти і навчання: збірник матеріалів ХІІ звітної Всеукраїнської науково-практичної конференції. Київ, Україна, 19 Березень 2018. Київ: б.в., с. 38-41.

Закатнов, Д. О., 2012. Технології підготовки учнівської молоді до професійного самовизначення: монография. Київ: Пед. думка, 2012.

Орлов, В. Ф., 2015. Проблеми проектування професійної кар'єри майбутніх фахівців із дизайну. Мистеиька освіта: зміст, технології, менеджмент: зб. наукових праџь, 10, с. 5-17.

Радкевич, В. О., 2010. Теоретичні і методичні засади професійного навчання у закладах профтехосвіти художнього профілю: монографія. К.: УкрIНТЕІ.

Радкевич, В. О., 2016. Теоретичні та методичні засади розвитку професійної освіти і навчання: результати, проблеми, перспективи. Науковий вісник Інститут професійно-технічної освіти НАПН України. Професійна педагогіка: зб. наук. пращь, 11, с. 5-23.

Радкевич, В.О., 2017. Професійна освіта і навчання: європейський контекст розвитку. Науковий вісник Інституту професійно-технічної освіти НАПН України. Професійна педагогіка: зб. наук. праџь, 14, с. 5-15.

\section{Translated \& Transliterated}

Alieksieieva, S. V., 2015. Informatsiine osvitnie seredovyshche pidhotovky maibutnikh dyzaineriv do rozvytku profesiinoi kariery [Building the information educational environment for training future designers to evolve their professional career]. Naukovyi visnyk Instytutu profesiino-tekhnichnoi osvity NAPN Ukrainy. Profesiina pedahohika [Scientific Herald of the Institute of Vocational Education and Training of the National Academy of Pedagogical Sciences of Ukraine. Vocational pedagogy], 10, s. 72-78, [in Ukrainian].

Alieksieieva, S. V., 2016. Formy ta metody on-lain konsultuvannia maibutnikh fakhivtsiv z rozvytku profesiinoi kariery [Forms and methods of on-line counseling on professional career development for future specialists]. Suchasni informatsiini tekhnolohii ta innovatsiini metodyky navchannia v pidhotovtsi fakhivtsiv: metodolohiia, teoriia, dosvid, problemy [Modern information technologies and innovative training methods for specialists training: methodology, theory, experience, problems], 44, s. 194-198, [in Ukrainian].

Bazyl, L. ta Orlov, V., 2018. Konsultuvannia iz profesiinoi kariery yak vazhlyvyi chynnyk samorealizatsii maibutnikh fakhivtsiv [Professional career counseling as an important factor for future specialists' self-realisation]. Science and education a new dimension. Pedagogy and Psychology, [Science and education a new dimension. Pedagogy and Psychology] VI (75), Issue 181, Nov, s. 7-11, [in Ukrainian].

Yershova, L. M., 2017. Henderni osoblyvosti motyvatsii uchniv profesiino-tekhnichnykh navchalnykh zakladiv do vyboru profesii ta rozvytku profesiinoi kariery [Gender features of VET schools students motivation for choosing the occupation and professional career development]. Naukovo-metodychne zabezpechennia profesiinoi osvity i navchannia [Scientific and methodological support for vocational education and training]: zbirnyk materialiv XI Vseukrainskoi naukovo-praktychnoi konferentsii (zvitnoi), prysviachenoi 25-richchiu NAPN Ukrainy. Kyiv, Ukraina, 29 Berezen - 13 Kviten 2017, s. 134-137, [in Ukrainian].

Yershova, L., 2018. Naukovo-eksperymentalni doslidzhennia yak motyvator rozvytku profesiinoi kariery [Scientificexperimental researches as professional career development motivator]. V: Naukovo-metodychne zabezpechennia profesiinoi osvity i navchannia [Scientific and methodological support for vocational education and training]: zbirnyk materialiv XII zvitnoi Vseukrainskoi naukovo-praktychnoi konferentsii. Kyiv, Ukraina, 19 Berezen 2018. Kyiv: b.v., s. 38-41, [in Ukrainian]. 
Zakatnov, D. O., 2012. Tekhnolohii pidhotovky uchnivskoi molodi do profesiinoho samovyznachennia: monohrafyia [Training technologies for getting the youth ready for professional sefl-determination]. Kyiv: Ped. dumka [Pedagogic thought], 2012, [in Ukrainian].

Orlov, V. F., 2015. Problemy proektuvannia profesiinoi kariery maibutnikh fakhivtsiv iz dyzainu [The problems of designing future professional career design specialists]. Mystetska osvita: zmist, tekhnolohii, menedzhment [Art Education: content, technologies, management], 10, s. 5-17, [in Ukrainian].

Radkevych, V. O., 2010. Teoretychni i metodychni zasady profesiinoho navchannia u zakladakh proftekhosvity khudozhnoho profiliu: monohrafiia [Theoretical and methodological basis for professional training in vocational institutions of the arts profile]. K.: UkrINTEI, [in Ukrainian].

Radkevych, V. O., 2016. Teoretychni ta metodychni zasady rozvytku profesiinoi osvity i navchannia: rezultaty, problemy, perspektyvy [Theoretical and methodological basis of VET development: results, problems, prospective]. Naukovyi visnyk Instytut profesiino-tekhnichnoi osvity NAPN Ukrainy. Profesiina pedahohika [Scientific herald of the Institute of vocational education and training of NAES of Ukraine. Professional Pedagogy], 11, s. 5-23, [in Ukrainian].

Radkevych, V.O., 2017. Profesiina osvita i navchannia: yevropeiskyi kontekst rozvytku [Vocational education and training: European context of development]. Naukovyi visnyk Instytutu profesiino-tekhnichnoi osvity NAPN Ukrainy. Profesiina pedahohika: zb. nauk. prats [Scientific herald of the Institute of vocational education and training of NAES of Ukraine. Professional Pedagogy: Collection of scientific works], 14, s. 5-15, [in Ukrainian].

УДК 378:7.012]:005.96-027.561

\section{Підготовка майбутніх дизайнерів до розвитку професійної кар'єри: результати педагогічного експерименту та перспективи досліджень}

\section{Валентина Радкевич ${ }^{1}$, Світлана Алєкссєва ${ }^{2}$,}

1 доктор педагогічних наук, професор, дійсний член НАПН України директор Інституту професійно-технічної освіти НАПН України

2 кандидат педагогічних наук старший науковий співробітник лабораторії професійної кар'єри Інституту професійнотехнічної освіти НАПН України

Реферат. Проблема кар'єрного розвитку особистості стає актуальною в сучасній педагогіці та розглядається як свідомо обраний шлях досягнення вершин її професійної довершеності, самореалізації й успішного утвердження в суспільстві. Сучасна підготовка майбутніх дизайнерів до розвитку професійної кар'єри здійснюється на засадах діалогової взаємодії через упровадження партисипативних практик (причетності), технологій фасилітації (групової роботи), вітагенних технологій (актуалізація життєвого досвіду). Важливою особливістю підготовки майбутніх дизайнерів до розвитку професійної кар'єри стало використання інформаційно-комунікаційних технологій та засобів (соціальні мережі, "хмарні" сервіси, електронно-комунікативні ресурси, програми мультимедіа, інформаційно-візуальні системи), які організовано у вигляді єдиного інформаційно-освітнього середовища. Розроблення відповідного змісту підготовки як цілісної системи, що включає три основні компоненти: когнітивний (знання), процесуальний (уміння, навички), особистісний (особистісні якості, ціннісні орієнтації, емоційні стани) та активне використання інноваційних технологій (формування мотивації до розвитку професійної кар'єри; формування у майбутніх дизайнерів знань і вмінь із розвитку професійної кар'єри; організація самоосвітньої діяльності з розвитку професійної кар'єри) значно сприяло підвищенню рівня підготовленості майбутніх дизайнерів до розвитку професійної кар'єри. Результати педагогічного експерименту уможливлюють визначення перспективних напрямів підготовки майбутніх дизайнерів до розвитку професійної кар'єри, серед яких: удосконалення системи консультування з розвитку професійної кар'єри та створення відповідної інформаційної мережі, надання психологічних і діагностичних послуг із професійної орієнтації й визначення рівня підготовленості до розвитку професійної кар'єри; розроблення освітніх програм, зорієнтованих на професійний і кар'єрний розвиток; удосконалення підготовки і перепідготовки педагогічних працівників до здійснення цього процесу; упорядкування управлінських дій та розроблення системи заходів, спрямованих на розв'язання означеної проблеми.

Ключові слова: професійна кар'єра; інформаційно-навчальний сайт; онлайн-консультування; інформаційнокомунікаційні засоби; методи стимулювання та актуалізації життєвого досвіду.

Received: 15 May 2019

Accepted: 24 May 2019 